\title{
Article \\ Phenol Derivatives as Co-Crystallized Templates to Modulate Trimesic-Acid-Based Hydrogen-Bonded Organic Molecular Frameworks
}

\author{
Guangchuan $\mathrm{Ou}{ }^{1, *}$, Qiong Wang ${ }^{1}$, Qiang Zhou ${ }^{1}$ and Xiaofeng Wang ${ }^{2} \mathbb{D}$ \\ 1 College of Chemistry and Bioengineering, Hunan University of Science and Engineering, \\ Yongzhou 425199, Hunan, China; wqiong1975@huse.cn (Q.W.); zhouq7712@huse.cn (Q.Z.) \\ 2 School of Chemistry and Chemical Engineering, University of South China, Hengyang 421001, Hunan, China; \\ xfwang518@usc.edu.cn \\ * Correspondence: ogcouguangchuan@huse.cn; Tel.: +86-746-6381164
}

check for updates

Citation: Ou, G.; Wang, Q.; Zhou, Q.; Wang, X. Phenol Derivatives as Co-Crystallized Templates to

Modulate Trimesic-Acid-Based Hydrogen-Bonded Organic Molecular Frameworks. Crystals 2021, 11,409. https://doi.org/10.3390/ cryst11040409

Academic Editors: Maija Nissinen and Edward R.T. Tiekink

Received: 17 March 2021

Accepted: 8 April 2021

Published: 12 April 2021

Publisher's Note: MDPI stays neutral with regard to jurisdictional claims in published maps and institutional affiliations.

Copyright: (c) 2021 by the authors. Licensee MDPI, Basel, Switzerland. This article is an open access article distributed under the terms and conditions of the Creative Commons Attribution (CC BY) license (https:// creativecommons.org/licenses/by/ $4.0 /)$.

\begin{abstract}
Five host-guest trimesic-acid-based hydrogen-bonds framework compounds with different guests, namely $\left[(\mathrm{TMA})_{4} \cdot(\mathrm{TMB})_{3}\right](\mathbf{1}),\left[(\mathrm{TMA})_{2} \cdot(\mathrm{DMB})_{1.5}\right](2),\left[(\mathrm{TMA})_{6} \cdot(\mathrm{MP})\right](3),[(\mathrm{TMA}) \cdot(\mathrm{EP})]$ (4) and [(TMA).(PP)] (5) (TMA = trimesic acid, TMB = 1,3,5-trimethoxybenzene, DMB = 1,4dimethoxybenzene, $\mathrm{MP}=4$-methoxyphenol, $\mathrm{EP}=4$-ethoxyphenol and $\mathrm{PP}=4$-propoxyphenol), were obtained through co-crystallization, and were characterized by elemental analysis, infrared spectroscopy analysis, and thermogravimetric analysis. The trimesic acid molecules comprise a hydrogen bonding six-membered cyclic host network that is found in a two-dimensional arrangement in compounds $\mathbf{1}$ and $\mathbf{2}$, and in a nine-fold interpenetrated three-dimensional structure in compound 3. In compounds 4 and 5, the trimesic acid and EP/PP molecules form a hydrogenbonded six-membered cyclic network, resulting in a one-dimensional chain structure through $\mathrm{O}-\mathrm{H} \ldots$... O hydrogen bonds.
\end{abstract}

Keywords: trimesic acid; hydrogen bonding; co-crystallization

\section{Introduction}

The design and assembly of hydrogen-bonded organic frameworks (HOFs) or supramolecular-organic frameworks (SOFs) has attracted intense interest because of the great potential of these frameworks in many materials science and solid-state applications [1-9]. Among the various components use in hydrogen-bonded assemblies, multi-carboxylates have been used in numerous HOFs due to the wide variety of their spacers and angles. Trimesic acid (TMA) with the $\alpha$-polymorph structure with three carboxylate groups was first reported in 1969 [10] and is still an important building block for the construction of HOFs or SOFs due to its predictable honeycomb crystal lattice structure formation [11-13]. The crystal structure of the $\alpha$-polymorph displays the infinite hydrogen-bonded chicken-wire network formed by $\mathrm{R}_{2}{ }^{2}(8)$ dimerization of carboxylic acid groups. In the absence of a co-crystal template, TMA constructs infinite two-dimensional hydrogen-bonded networks through eight-member hydrogen bond synthons with hexagonal apertures with a diameter of approximately $14 \AA$ (Scheme 1). Many chemists attempted to remove the concatenation and fill the cavity at the center of the hexametric rings with guest molecules such as tetradecane and pyrenes [14-17].

Recently, several new methods for structure elucidation of small molecules were reported such as the use of tetraaryladamantanes as crystallization chaperones in cocrystallization [18], and the high-throughput nanoscale crystallization of organic-soluble small molecules (encapsulated nanodroplet crystallization) [19]. However, no universal chaperones co-crystallizing with various small molecule [20] such as porphyrins, calixarenes or cyclodextrins with a proven ability to obtain the structure of a broad range of different organic molecules have been reported [21-28]. In this work, building on the 
above-mentioned approaches, five trimesic acid co-crystallization hydrogen bond systems were obtained by the introduction of small phenols with different derivatives, namely 1,3,5-trimethoxybenzene (TMB), 1,4-dimethoxybenzene (DMB), 4-methoxyphenol (MP), 4-ethoxyphenol (EP), and 4-propoxyphenol (PP) (Scheme 1).

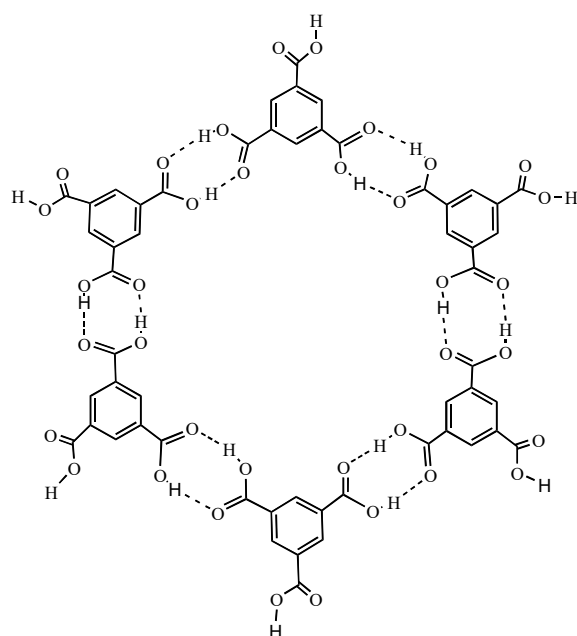

(I)<smiles>COc1cc(OC)cc(OC)c1</smiles><smiles>COc1ccc(OC)cc1</smiles>

DMB

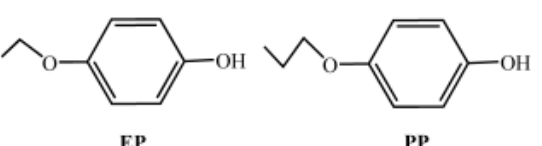

(II)

Scheme 1. (I) Infinite two-dimensional hydrogen-bonded networks in trimesic acid, (II) structures of trimesic acid and phenol derivatives.

\section{Materials and Methods}

All the chemicals (98\% purity) were obtained from Shanghai Xianding Biotechnology Co., Ltd. (Shanghai, China) and were used without further purification. Elemental analyses were carried out using an Elementar Micro Cube elemental analyzer (Elementar, Hesse, Germany). Infrared spectra were recorded in the $4000-400 \mathrm{~cm}^{-1}$ region using $\mathrm{KBr}$ pellets and a Bruker EQUINOX 55 spectrometer (Bruker, Karlsruhe, Germany). Thermogravimetric analyses were performed using a Netzsch STA 449F3 instrument (Netzsch, Bavaria, Germany) in flowing air at a heating rate of $10^{\circ} \mathrm{C} \cdot \mathrm{min}^{-1}$. X-ray powder diffraction data were recorded using a Bruker D8 ADVANCE X-ray powder diffractometer $(\mathrm{Cu} \mathrm{K} \alpha$ radiation, $\lambda=1.5418 \AA$, Bruker, Germany).

\subsection{Preparation of the Compounds}

[(TMA) $)_{4} \cdot(\mathrm{TMB})_{3}$ ] (1): A solution of trimesic acid (TMA, $\left.210 \mathrm{mg}, 1 \mathrm{mmol}\right)$ in methanol $(5 \mathrm{~mL})$ was added to a methanol solution of 1,3,5-trimethoxybenzene (TMB, $168 \mathrm{mg}$, $1 \mathrm{mmol})$. The resulting solution was evaporated slowly at room temperature. After a few days, suitable single crystals were obtained. Elemental Analysis Found: C, 56.45\%; H, $4.68 \%$. Calculated for $\mathrm{C}_{126} \mathrm{H}_{121} \mathrm{O}_{66}: \mathrm{C}, 56.23 \%$; H, 4.53\%. IR (KBr): $3556(\mathrm{~m}), 3455(\mathrm{~m}), 3093$

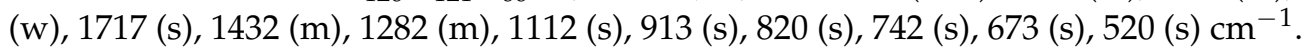

[(TMA $\left.)_{2} \cdot(\mathrm{DMB})_{1.5}\right](\mathbf{2})$ : Similar to the synthesis of compound (1), the use of 1,4dimethoxybenzene (DMB, $138 \mathrm{mg}, 1 \mathrm{mmol}$ ) instead of TMB gave crystals of (2). Elemental Analysis Found: C, 57.75\%; H, 4.23\%. Calculated for $\mathrm{C}_{30} \mathrm{H}_{27} \mathrm{O}_{15}: \mathrm{C}, 57.42 \% ; \mathrm{H}, 4.34 \%$. IR (KBr): 3086 (w), 3002 (w), $2872(\mathrm{w}), 1721$ (s), 1607 (m), 1508 (m), 1455 (m), 1403 (s), 1276(m), 1107 (s), 1049 (m), 914 (s), 743 (s), 691 (s), $612(\mathrm{~m}) \mathrm{cm}^{-1}$.

[(TMA) $\left.)_{6} \cdot(\mathrm{MP})\right]$ (3): Similar to the synthesis of compound (1), the use of 4-methoxyphenol (MP, $124 \mathrm{mg}, 1 \mathrm{mmol}$ ) instead of TMB gave crystals of (3). Elemental Analysis Found: C, $51.38 \%$; H, 3.26\%. Calculated for $\mathrm{C}_{121} \mathrm{H}_{104} \mathrm{O}_{80}\left(3 \cdot 6 \mathrm{CH}_{3} \mathrm{OH}\right): \mathrm{C}, 51.20 \%$; H, 3.69\%. IR (KBr): 3090 (w), 1720 (s), 1606 (m), 1510 (m), 1455 (m), 1404 (s), 1275 (s), 1107 (m), 915 (s), 742 (s), 690 (s), $536(\mathrm{~s}) \mathrm{cm}^{-1}$. 
[(TMA) ·(EP)] (4): Similar to the synthesis of compound (1), the use of 4-methoxyphenol (EP, $138 \mathrm{mg}, 1 \mathrm{mmol}$ ) instead of TMB gave crystals of (4). Elemental Analysis Found: C, $58.92 \% ; \mathrm{H}, 4.36 \%$. Calculated for $\mathrm{C}_{17} \mathrm{H}_{16} \mathrm{O}_{8}$ : C, 58.62\%; H, 4.63\%. IR (KBr): $3083(\mathrm{w}), 2934$ (w), $1725(\mathrm{~s}), 1511(\mathrm{~s}), 1451(\mathrm{~m}), 1282(\mathrm{~s}), 1202(\mathrm{~m}), 1110(\mathrm{~m}), 975(\mathrm{~m}), 829(\mathrm{~s}), 741(\mathrm{~s}), 686(\mathrm{~s})$, $518(\mathrm{~s}) \mathrm{cm}^{-1}$.

[(TMA) -(PP)] (5): Similar to the synthesis of compound (1), the use of 4-methoxyphenol (PP, $152 \mathrm{mg}, 1 \mathrm{mmol}$ ) instead of TMB gave crystals of (5). Elemental Analysis Found: C, $59.91 \% ; \mathrm{H}, 5.36 \%$. Calcd for $\mathrm{C}_{18} \mathrm{H}_{18} \mathrm{O}_{8}$ : C, 59.67\%; H, 5.00\%. IR (KBr): $3075(\mathrm{w}), 2929(\mathrm{w})$, $1721(\mathrm{~s}), 1606(\mathrm{~m}), 1510(\mathrm{~m}), 1402(\mathrm{~m}), 1278(\mathrm{~m}), 1108(\mathrm{~m}), 936(\mathrm{~m}), 830(\mathrm{~m}), 742(\mathrm{~s}), 686(\mathrm{~s})$, $519(\mathrm{~s}) \mathrm{cm}^{-1}$.

\subsection{Crystal Structure Determination}

Single-crystal data for (1)-(5) were collected using a Bruker Smart Apex II diffractometer (Bruker, Germany) with Mo-K $\alpha$ radiation $(\lambda=0.71073 \AA$ ). All empirical absorption corrections were applied using the SADABS program [29]. The structures were solved using direct methods that yielded the positions of all non-hydrogen atoms. These positions were refined first isotropically and then anisotropically. All calculations were performed using the SHELXTL software package [30]. The crystallographic data of (1)-(5) are summarized in Table 1. The parameters of the hydrogen bonds in the crystal structures of (1)-(5) are listed in Table 2.

Table 1. Crystallographic data.

\begin{tabular}{|c|c|c|c|c|c|}
\hline Compound & (1) & (2) & (3) & (4) & (5) \\
\hline Empirical formula & $\mathrm{C}_{126} \mathrm{H}_{121} \mathrm{O}_{66}$ & $\mathrm{C}_{30} \mathrm{H}_{27} \mathrm{O}_{15}$ & $\mathrm{C}_{115} \mathrm{H}_{80} \mathrm{O}_{74}$ & $\mathrm{C}_{17} \mathrm{H}_{16} \mathrm{O}_{8}$ & $\mathrm{C}_{18} \mathrm{H}_{18} \mathrm{O}_{8}$ \\
\hline Formula weight & 2691.22 & 627.51 & 2645.79 & 348.30 & 362.32 \\
\hline Temperature (K) & $296(2)$ & $173(2)$ & $173(2)$ & 296(2) & $296(2)$ \\
\hline Crystal size (mm) & $0.20 \times 0.20 \times 0.20$ & $0.46 \times 0.32 \times 0.28$ & $0.20 \times 0.20 \times 0.20$ & $0.42 \times 0.36 \times 0.28$ & $0.48 \times 0.36 \times 0.28$ \\
\hline Crystal system & Monoclinic & Triclinic & Monoclinic & Monoclinic & Monoclinic \\
\hline Space group & $\mathrm{C} 2 / \mathrm{c}$ & $P-1$ & $\mathrm{C} 2 / \mathrm{c}$ & $\mathrm{C} 2 / \mathrm{c}$ & $\mathrm{C} 2 / \mathrm{c}$ \\
\hline $\mathrm{a}(\AA)$ & $16.715(5)$ & $7.706(2)$ & $26.2843(4)$ & $12.577(9)$ & $12.860(3)$ \\
\hline $\mathrm{b}(\AA)$ & $28.504(8)$ & $13.570(3)$ & $16.4064(2)$ & $9.631(7)$ & $9.681(2)$ \\
\hline$c(\AA)$ & $14.879(7)$ & $15.392(3)$ & $26.3167(3)$ & $27.072(20)$ & $27.377(5)$ \\
\hline$\alpha\left(^{\circ}\right)$ & 90 & $110.579(2)$ & 90 & 90 & 90 \\
\hline$\beta\left(^{\circ}\right)$ & $112.843(3)$ & $96.250(3)$ & $90.104(1)$ & $97.067(9)$ & $96.884(2)$ \\
\hline$\gamma\left({ }^{\circ}\right)$ & 90 & $97.720(3)$ & 90 & 90 & 90 \\
\hline Volume $\left(\AA^{3}\right)$ & $6533(4)$ & $1472.0(6)$ & $11348.6(3)$ & $3254.0(4)$ & $3383.8(12)$ \\
\hline $\mathrm{Z}$ & 2 & 2 & 4 & 8 & 8 \\
\hline$D_{\mathrm{c}}\left(\mathrm{g} \cdot \mathrm{cm}^{-3}\right)$ & 1.368 & 1.416 & 1.549 & 1.422 & 1.422 \\
\hline$\mu\left(\mathrm{mm}^{-1}\right)$ & 0.112 & 0.115 & 1.159 & 0.114 & 0.113 \\
\hline $\mathrm{F}(000)$ & 2810 & 654 & 5448 & 1456 & 1520 \\
\hline $\begin{array}{l}\text { Reflections } \\
\text { collected }\end{array}$ & 32175 & 16547 & 62726 & 17875 & 18282 \\
\hline $\begin{array}{l}\text { Unique reflections } \\
\qquad\left(R_{\text {int }}\right)\end{array}$ & $6062(0.0310)$ & $6531(0.0239)$ & $9093(0.0335)$ & $3730(0.0342)$ & $3480(0.0204)$ \\
\hline $\begin{array}{c}\text { Data/constraint/ } \\
\text { parameters }\end{array}$ & $6062 / 1062 / 720$ & $6531 / 6 / 427$ & $9093 / 79 / 900$ & $3730 / 1 / 233$ & $3480 / 1 / 242$ \\
\hline $\begin{array}{l}\text { Goodness-of-fit on } \\
\qquad \mathrm{F}^{2}\end{array}$ & 1.033 & 1.061 & 1.057 & 1.045 & 1.053 \\
\hline $\begin{array}{l}\text { Final } R \text { indices } \\
\quad[I>2 \sigma(I)]\end{array}$ & $\begin{array}{c}\mathrm{R}_{1}=0.0762 \\
\mathrm{wR}_{2}=0.2074\end{array}$ & $\begin{array}{c}\mathrm{R}_{1}=0.0488 \\
\mathrm{wR}_{2}=0.1396\end{array}$ & $\begin{array}{c}\mathrm{R}_{1}=0.0480 \\
\mathrm{wR}_{2}=0.1429\end{array}$ & $\begin{array}{c}\mathrm{R}_{1}=0.0499 \\
\mathrm{wR}_{2}=0.1347\end{array}$ & $\begin{array}{c}\mathrm{R}_{1}=0.0663 \\
\mathrm{wR}_{2}=0.1891\end{array}$ \\
\hline$R$ indices (all data) & $\begin{array}{c}\mathrm{R}_{1}=0.1140 \\
\mathrm{wR}_{2}=0.2339\end{array}$ & $\begin{array}{c}\mathrm{R}_{1}=0.0662 \\
\mathrm{w} \mathrm{R}_{2}=0.1561\end{array}$ & $\begin{array}{c}\mathrm{R}_{1}=0.0513 \\
\mathrm{wR}_{2}=0.1460\end{array}$ & $\begin{array}{c}\mathrm{R}_{1}=0.0762 \\
\mathrm{wR}_{2}=0.1519\end{array}$ & $\begin{array}{c}\mathrm{R}_{1}=0.0824 \\
\mathrm{w} \mathrm{R}_{2}=0.2052\end{array}$ \\
\hline $\begin{array}{l}\text { Largest diff. peak } \\
\text { and hole } \\
\left(\mathrm{e} \cdot \AA^{-3}\right)\end{array}$ & 0.568 and -0.404 & 0.355 and -0.389 & 0.417 and -0.571 & 0.275 and -0.202 & 0.678 and -0.322 \\
\hline
\end{tabular}


Table 2. Hydrogen bond parameters $\left(\AA,^{\circ}\right)$ for the crystal structures of $(\mathbf{1})-(\mathbf{5})$.

\begin{tabular}{|c|c|c|c|c|}
\hline \multicolumn{5}{|c|}{ (1) } \\
\hline D-H $\cdots A$ & $\mathrm{~d}(\mathrm{D}-\mathrm{H})$ & $\mathrm{d}(\mathrm{H} \cdots \mathbf{A})$ & $d(D \cdots A)$ & $<$ (DHA) \\
\hline O1_1-H1_1‥O3_2 & 0.82 & 1.83 & 2.63 & 168.3 \\
\hline O3_1-H3A_1 $\cdots$ O1_2 & 0.82 & 1.83 & 2.64 & 170.6 \\
\hline $\mathrm{O} 2 \_2-\mathrm{H} 2 \mathrm{~A} \_2 \cdots \mathrm{O} 2 \_1^{\# 4}$ & 1.03 & 1.62 & 2.64 & 169.0 \\
\hline O3_2-H3A_2 $\cdots$ O1_1_1 & 0.82 & 1.83 & 2.63 & 168.0 \\
\hline $\mathrm{O} 2 \_3-\mathrm{H} 2 \_3 \cdots \mathrm{O} 1 \_3^{\# 3}$ & 0.96 & 1.68 & 2.64 & 176.5 \\
\hline O3_3-H3A_3 $\cdots$ O4_3 $3^{\# 1}$ & 0.82 & 1.84 & 2.65 & 168.1 \\
\hline O6_3-H6A_3 $\cdots O$ O5_3 & 0.96 & 1.68 & 2.64 & 176.3 \\
\hline
\end{tabular}

Symmetry codes: \#1 $-x+1,-y+1,-z+1 ; \# 2-x+1 / 2,-y+1 / 2,-z+1 ; \# 3-x+3 / 2,-y+1 / 2$, $-z+1 ; \# 4 x-1 / 2,-y+1 / 2, z-1 / 2 ; \# 5 x+1 / 2,-y+1 / 2, z+1 / 2$.

\begin{tabular}{|c|c|c|c|c|}
\hline \multicolumn{5}{|c|}{ (2) } \\
\hline D-H ...A & $\mathrm{d}(\mathrm{D}-\mathrm{H})$ & $\mathrm{d}(\mathrm{H} \cdots \mathrm{A})$ & $d(D \cdots A)$ & $<$ (DHA) \\
\hline O1-H1D $\cdots \mathrm{O} 12^{\# 1}$ & 0.88 & 1.73 & 2.62 & 176.0 \\
\hline 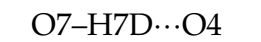 & 0.87 & 1.73 & 2.59 & 173.0 \\
\hline O6-H6D $\cdots \mathrm{O}^{\# 2}$ & 0.88 & 1.73 & 2.59 & 167.0 \\
\hline O3-H3D $\cdots$ O8 & 0.86 & 1.75 & 2.60 & 176.0 \\
\hline O10-H10D $\cdots \mathrm{O}^{\# 3}$ & 0.89 & 1.72 & 2.60 & 170.0 \\
\hline $\mathrm{O} 11-\mathrm{H} 11 \mathrm{D} \cdots \mathrm{O} 2^{\# 4}$ & 0.88 & 1.74 & 2.61 & 173.0 \\
\hline
\end{tabular}

Symmetry codes: $\# 1 x+1, y, z+1 ; \# 2 x+1, y-1, z ; \# 3 x-1, y+1, z ; \# 4 x-1, y, z-1$.

(3)

\begin{tabular}{|c|c|c|c|c|}
\hline $\mathrm{D}-\mathrm{H} \cdots \mathrm{A}$ & $d(D-H)$ & $\mathrm{d}(\mathrm{H} \cdots \mathrm{A})$ & $d(D \cdots A)$ & $<$ (DHA) \\
\hline $\mathrm{O} 15-\mathrm{H} 15 \cdots \mathrm{O} 26^{\# 7}$ & 0.84 & 1.76 & 2.60 & 174.5 \\
\hline O9-H9...O18 & 0.84 & 1.83 & 2.65 & 168.3 \\
\hline 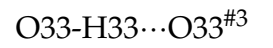 & 0.84 & 1.81 & 2.63 & 165.3 \\
\hline $\mathrm{O} 12-\mathrm{H} 12 \cdots \mathrm{O} 13^{\# 10}$ & 0.84 & 1.82 & 2.64 & 166.3 \\
\hline 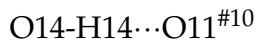 & 0.84 & 1.87 & 2.69 & 167.9 \\
\hline $\mathrm{O} 17-\mathrm{H} 17 \cdots \mathrm{O} 10^{\# 11}$ & 0.84 & 1.77 & 2.60 & 175.2 \\
\hline O7-H7B $\cdots O 4^{\# 9}$ & 0.84 & 1.80 & 2.64 & 175.0 \\
\hline $\mathrm{O} 27-\mathrm{H} 27 \mathrm{~B} \cdots \mathrm{O} 36^{\# 5}$ & 0.84 & 1.80 & 2.63 & 170.0 \\
\hline $\mathrm{O} 25-\mathrm{H} 25 \mathrm{~B} \cdots \mathrm{O} 16^{\# 7}$ & 0.84 & 1.81 & 2.65 & 176.3 \\
\hline $\mathrm{O} 5-\mathrm{H} 5 \mathrm{~B} \cdots \mathrm{O} 22^{\# 2}$ & 0.84 & 1.78 & 2.61 & 168.4 \\
\hline $\mathrm{O} 32-\mathrm{H} 32 \mathrm{~B} \cdots \mathrm{O} 29^{\# 5}$ & 0.84 & 1.80 & 2.63 & 169.4 \\
\hline 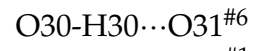 & 0.84 & 1.78 & 2.61 & 168.0 \\
\hline $\mathrm{O} 21-\mathrm{H} 21 \mathrm{~B} \cdots \mathrm{O} 6^{\# 1}$ & 0.84 & 1.82 & 2.65 & 168.8 \\
\hline $\mathrm{O} 35-\mathrm{H} 35 \mathrm{~B} \cdots \mathrm{O} 28^{\# 6}$ & 0.84 & 1.78 & 2.62 & 172.1 \\
\hline $\mathrm{O} 2-\mathrm{H} 2 \mathrm{~B} \cdots \mathrm{O} 23$ & 0.84 & 1.82 & 2.65 & 172.4 \\
\hline O34-H34В $\cdots$ O34 & 0.84 & 1.84 & 2.65 & 160.2 \\
\hline $\mathrm{O} 20-\mathrm{H} 20 \mathrm{~B} \cdots \mathrm{O} 20^{\# 4}$ & 0.84 & 1.81 & 2.64 & 167.6 \\
\hline O3-Н3В $\cdots$ O $8^{\# 8}$ & 0.84 & 1.77 & 2.61 & 173.7 \\
\hline O19-H19 $\cdots O 19^{\# 4}$ & 0.84 & 1.83 & 2.65 & 164.3 \\
\hline $\mathrm{O} 24-\mathrm{H} 24 \mathrm{~B} \cdots \mathrm{O} 1$ & 0.84 & 1.78 & 2.62 & 172.7 \\
\hline
\end{tabular}

Symmetry codes: \#1 $x, y-1, z ; \# 2 x, y+1, z ; \# 3-x+1, y,-z+1 / 2 ; \# 4-x+1, y,-z+3 / 2 ; \# 5-x$ $+1 / 2, y+1 / 2,-z+1 / 2 ; \# 6-x+1 / 2, y-1 / 2,-z+1 / 2 ; \# 7-x+1,-y+1,-z+1 ; \# 8 x,-y+1, z$ $-1 / 2$; \#9 $x,-y+1, z+1 / 2 ; \# 10-x+1 / 2,-y+1 / 2,-z+1 ; \# 11-x+1 / 2,-y+3 / 2,-z+1$. 
Table 2. Cont.

\begin{tabular}{|c|c|c|c|c|}
\hline \multicolumn{5}{|c|}{ (4) } \\
\hline $\mathrm{D}-\mathrm{H} \cdots \mathrm{A}$ & $d(D-H)$ & $\mathrm{d}(\mathrm{H} \cdots \mathbf{A})$ & $d(D \cdots A)$ & $<$ (DHA) \\
\hline $\mathrm{O} 2-\mathrm{H} 2 \cdots \mathrm{O}^{\# 1}$ & 0.82 & 1.83 & 2.65 & 175.3 \\
\hline $\mathrm{O} 4-\mathrm{H} 4 \cdots \mathrm{O} 1^{\# 2}$ & 0.82 & 1.86 & 2.63 & 156.4 \\
\hline O7-H7...O3 & 0.82 & 1.93 & 2.74 & 169.0 \\
\hline O5-H5D $\cdots \mathrm{O}^{\# 3}$ & 0.89 & 1.74 & 2.63 & $175(2)$ \\
\hline
\end{tabular}

Symmetry codes: \#1 $x, y+1, z ; \# 2 x, y-1, z ; \# 3-x+3 / 2,-y+3 / 2,-z+1$.

\begin{tabular}{|c|c|c|c|c|}
\hline \multicolumn{5}{|c|}{ (5) } \\
\hline D-H $\cdots A$ & $\mathrm{~d}(\mathrm{D}-\mathrm{H})$ & $\mathrm{d}(\mathrm{H} \cdots \mathrm{A})$ & $d(D \cdots A)$ & $<$ (DHA) \\
\hline $\mathrm{O} 1-\mathrm{H} 1 \cdots \mathrm{O} 7^{\# 1}$ & 0.82 & 1.84 & 2.65 & 171.2 \\
\hline $\mathrm{O} 7-\mathrm{H} 7 \cdots \mathrm{O}^{\# 2}$ & 0.82 & 1.94 & 2.75 & 169.7 \\
\hline $\mathrm{O} 5-\mathrm{H} 5 \cdots \mathrm{O} 2^{\# 3}$ & 0.82 & 1.89 & 2.64 & 151.7 \\
\hline O4-H4D $\cdots 3^{\# 4}$ & 0.99 & 1.65 & 2.64 & 176.0 \\
\hline
\end{tabular}

Symmetry codes: $\# 1 x-1, y-1, z ; \# 2 x+1, y, z ; \# 3 x, y+1, z ; \# 4-x+1 / 2,-y+1 / 2,-z+2$

\section{Results and Discussion}

\subsection{Description of Structures}

\subsubsection{Quaternary Compound $\left[(\mathrm{TMA})_{4} \cdot(\mathrm{TMB})_{3}\right](\mathbf{1})$}

Co-crystallization of TMA and TMB from a methanol solution gave high-quality crystals that were then characterized by single-crystal X-ray diffraction. It was found that compound (1) crystallizes in a monoclinic cell in the C2/c space group, and contains three TMA and two TMB crystallographically independent molecules per asymmetric unit (Figure S1). Differences between the three TMA molecules are marginal. The $\mathrm{C}-\mathrm{O}$ and $\mathrm{C}=\mathrm{O}$ bond distances of carboxy group are equalized in two TMA molecules. The monomers of compound (1) are interconnected through double hydrogen bonds to form a hexagonal honeycomb motif with $h c b$ topology. The six TMA molecules define a macrocyclic cavity with a diameter of $14 \AA$. Two types of infinite two-dimensional sheets alternating with one-dimensional channels are formed by three crystallographically independent TMA molecules through $\mathrm{O}-\mathrm{H} \cdots \mathrm{O}$ hydrogen bonding. The first type of sheet is comprised by the first kind of crystallographically independent TMA molecules and the second type of sheet is comprised by the other two kinds of crystallographically independent TMA molecules (Figure 1). The channels are filled with two types of crystallographically independent guest TMB molecules in a disordered arrangement (Figure 1). Compound (1) was stabilized by $\pi-\pi$ stacking and $\mathrm{O}-\mathrm{H} \cdots \mathrm{O}$ hydrogen bonding interactions.

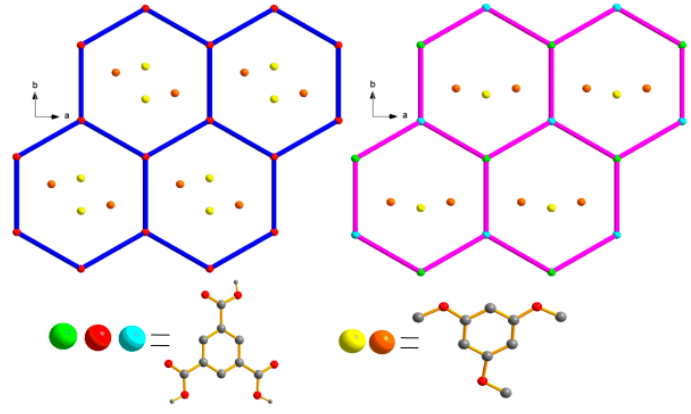

(I)

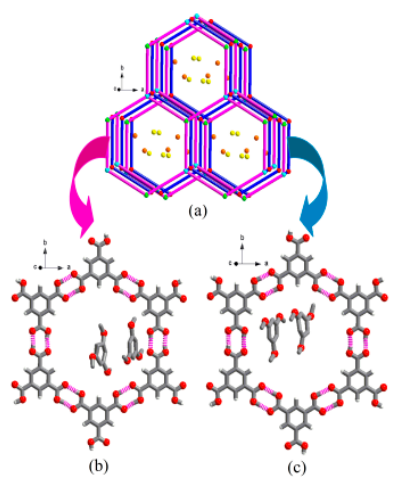

(II)

Figure 1. (I) TMB molecules located in the channels formed hydrogen-bonded 6-rings in compound (1); (II) two hydrogen-bonded 6-membered rings in compound (1). 


\subsubsection{Quaternary Compound [(TMA $\left.)_{2} \cdot(\mathrm{DMB})_{1.5}\right](2)$}

Co-crystallization of TMA and DMB from a methanol solution in a 2:1.5 ratio in an asymmetric unit cell produces compound (2) (Figure S2). Single-crystal X-ray diffraction indicates that compound (2) crystallizes in a triclinic cell with the $P-1$ space group. Similar to compound (1), the monomers of compound (2) are interconnected through double hydrogen bonds to form a hexagonal honeycomb geometry (Figure 2). The six TMA molecules interact with each other to form a void space with the dimensions of $14 \AA \times 14 \AA$ through pairwise hydrogen bonding patterns. The crystal contains two types of infinite two-dimensional sheets arranged by two crystallographically independent TMA molecules. The channels are occupied by two types of crystallographically independent guest DMB molecules (Figures 2 and 3).

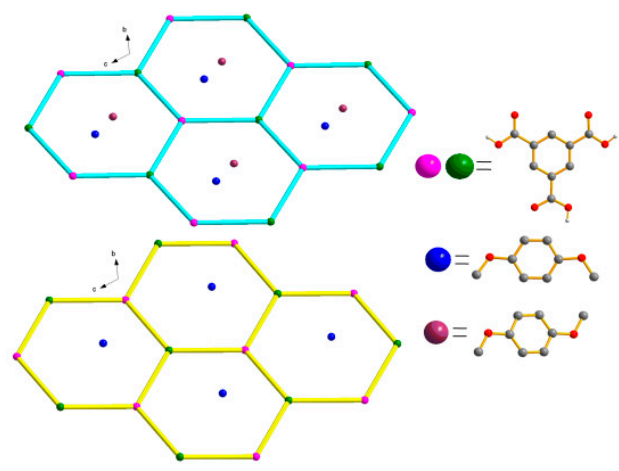

(I)

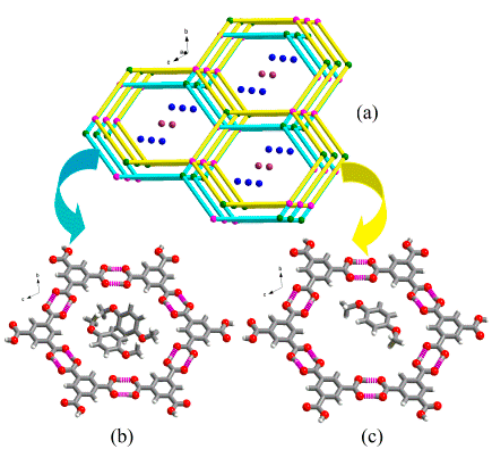

(II)

Figure 2. (I) DMB molecules located in the channels formed hydrogen-bonded 6-membered rings in compound (2); (II) two hydrogen-bonded 6-member rings in compound (2).

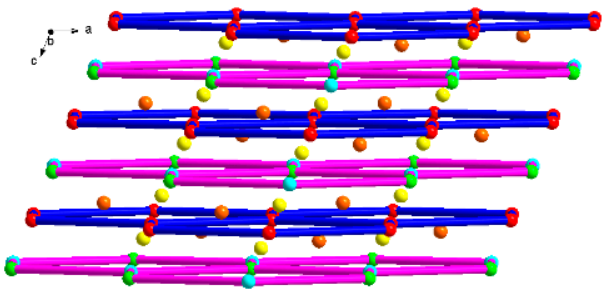

(I)

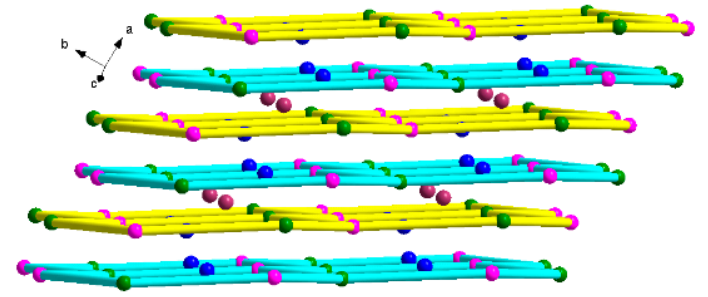

(II)

Figure 3. (I) Two-dimensional hydrogen-bonded sheets along the $b$ axis in compound (1); (II) Two-dimensional hydrogen-bonded sheets along the $c$ axis in compound (2).

\subsubsection{Quaternary Compound $\left[(\mathrm{TMA})_{6} \cdot(\mathrm{MP})\right](3)$}

Co-crystallization of TMA and MP from a methanol solution in a 6:1 ratio in an asymmetric unit cell produced compound (3) (Figure S3). Single-crystal X-ray diffraction reveals that the compound (3) crystallizes in a monoclinic cell with the $\mathrm{C} 2 / \mathrm{c}$ space group. Similar to a previous report [7], the monomers of compound (3) are interconnected to give a hexagonal honeycomb with a void space dimensions of $14 \AA \times 14 \AA$ through double hydrogen bonds. The hexagonal honeycombs interact with each other to form waveform two-dimensional sheets, and the infinite waveform two-dimensional sheets concatenated each other to form a three-dimensional structure with cavities occupied by MP molecules (Figure 4). The three-dimensional structure is described as 9-fold interpenetration as shown in Figure $5 \mathrm{I}$ in which four identical waveform two-dimensional sheets are chosen randomly and viewed along the $b$ axis. 


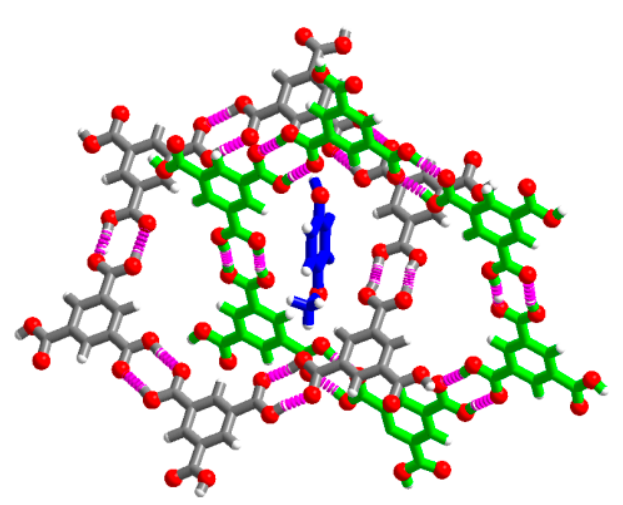

(I)

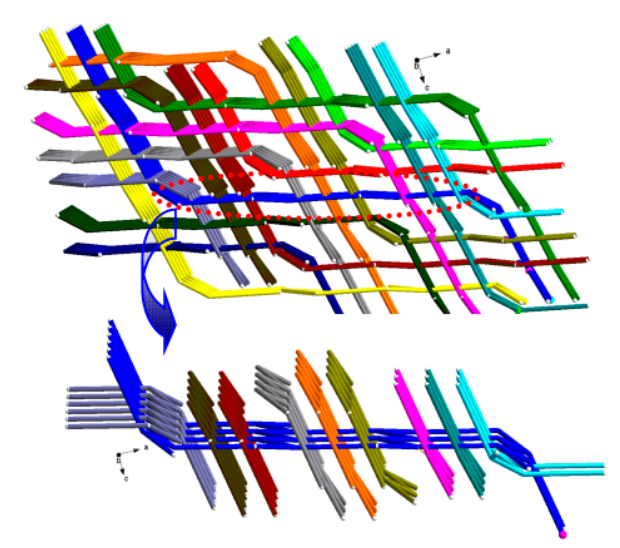

(II)

Figure 4. (I) MP molecules located in the cavities formed cross hydrogen-bonded 6-rings in compound (3); (II) nine-fold interpenetration of three-dimensional structure along the $b$ axis in compound (3).

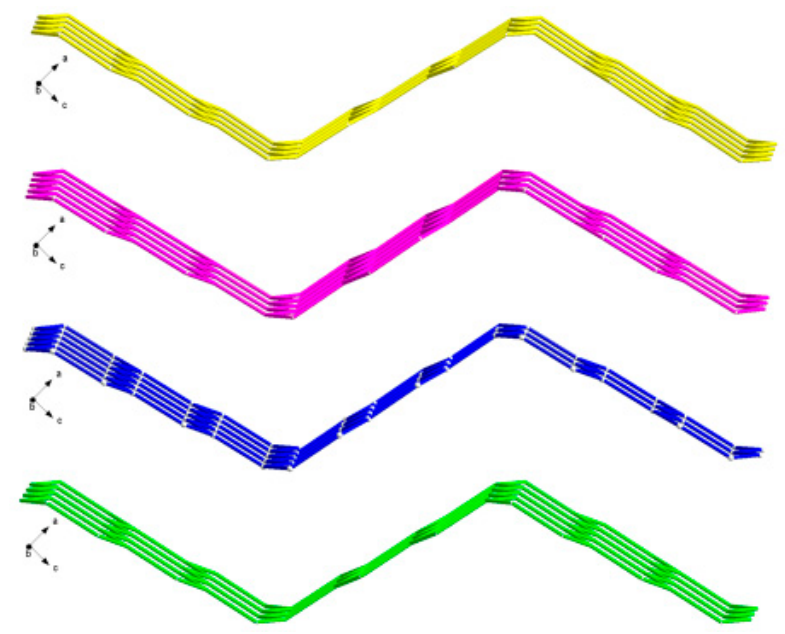

(I)

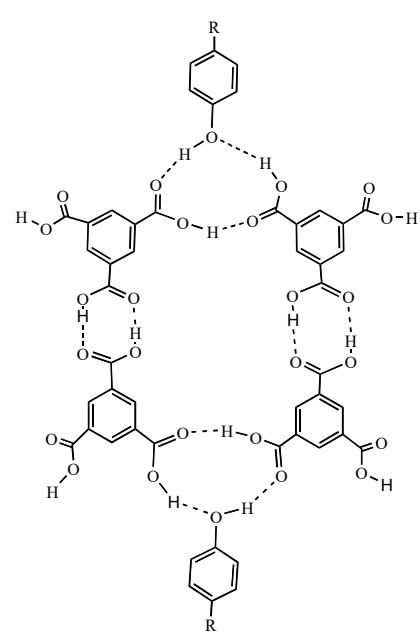

(II)

Figure 5. (I) Waveform two-dimensional hydrogen-bonded sheets are chosen randomly along the $b$ axis in compound (3); (II) the structure of hydrogen-bonded networks in compounds (4) and (5).

\subsubsection{Quaternary Compounds [(TMA) $\cdot(\mathrm{EP})]$ (4) and [(TMA) $\cdot(\mathrm{PP})](5)$}

Compounds (4) and (5) crystallized from a methanol solution in a 1:1 ratio in an asymmetric unit cell (Figures S4 and S5). Single-crystal X-ray diffraction reveals that both compounds (4) and (5) crystallize in a monoclinic cell with the $C 2 / \mathrm{c}$ space group. Unlike compounds (1)-(3), EP/PP replaced two TMA molecules and interconnected to form a tetragonal hole through $\mathrm{O}-\mathrm{H} \cdots \mathrm{O}$ hydrogen bonding as shown in Figure 5II. The tetragonal holes further interact with each other to form one-dimensional chains (Figure 6). 

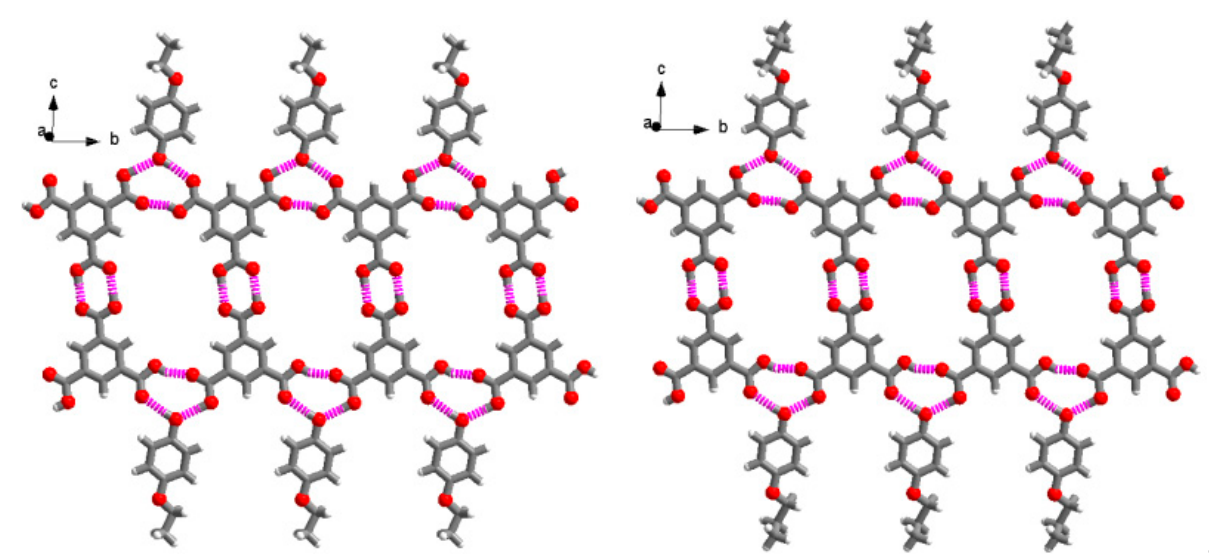

Figure 6. One-dimensional hydrogen-bonded chain along the $a$ axis in compounds (4) and (5).

\subsection{Thermogravimetric Analysis}

Thermogravimetric analysis (TGA) curves were obtained in flowing air at a heating rate of $10^{\circ} \mathrm{C} \cdot \mathrm{min}^{-1}$ in the temperature range from room temperature to $600{ }^{\circ} \mathrm{C}$. Compounds (1)-(5) are air stable and retain their structural integrity at room temperature. The TG curve of compound (1) first shows two consecutive weight losses of $12.2 \%$ each from 90 to $180^{\circ} \mathrm{C}$, corresponding to the release of two guest 1,3,5-trimethoxybenzene molecules (calculated, $12.5 \%$ ), and then another weight loss of $37.8 \%$ occurs in the $270-350{ }^{\circ} \mathrm{C}$ region, corresponding to the release of four guest 1,3,5-trimethoxybenzene molecules (calculated, $37.5 \%)$. The remaining host hydrogen bonding framework began to decompose upon further heating (Figure 7). Compound (2) reveals the first weight loss from 300 to $362{ }^{\circ} \mathrm{C}$, with the observed weight loss of $33.4 \%$ (calculated, 33.0\%) corresponding to the release of the guest 1,4-dimethoxybenzene molecules. For compound (3), similar to compound (2), the first weight loss of $48.6 \%$ was observed from 300 to $360{ }^{\circ} \mathrm{C}$, corresponding to the release of the trimesic acid, 4-methoxyphenol and solvent molecule. For compound (4), the two consecutive weight losses of $39.6 \%$ in the temperature range of $120-339{ }^{\circ} \mathrm{C}$ are close to the theoretical value of $39.7 \%$ for the loss of 4-ethoxyphenol. For compound (5), similar to compound (4), the two consecutive weight losses with a total of $41.9 \%$ in the temperature range of $120-355^{\circ} \mathrm{C}$ are close to the theoretical value of $42.0 \%$ for the loss of 4-propoxyphenol.

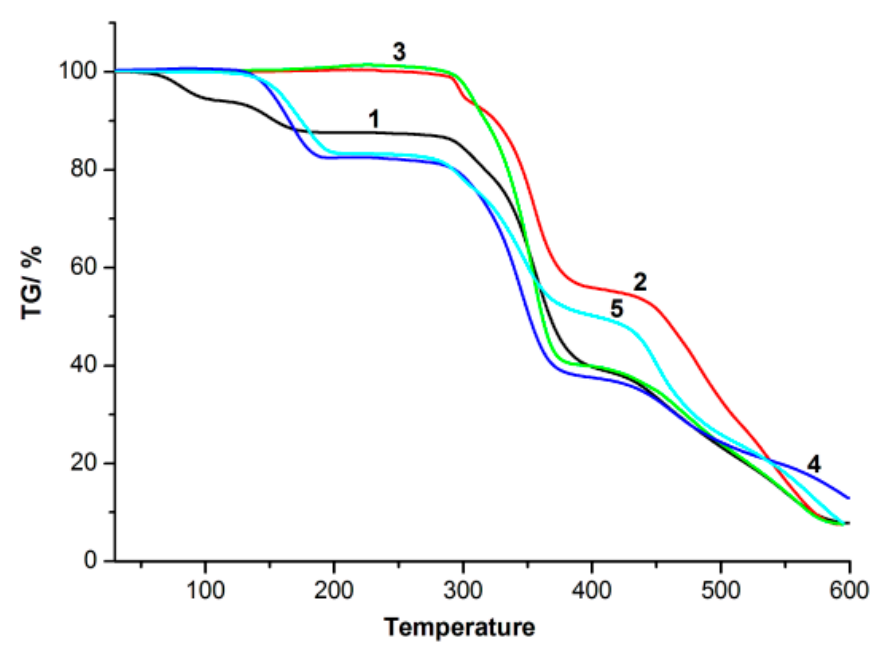

Figure 7. TG curves of compounds (1)-(5). 


\section{Conclusions}

In conclusion, we have demonstrated that host trimesic acid and guest phenol derivatives form different quaternary co-crystallization compounds that were stabilized by multiple $\pi-\pi$ stacking and $\mathrm{O}-\mathrm{H} \cdots \mathrm{O}$ hydrogen bonding interactions. The compounds presented here provide an opportunity to further design and construct host-guest organic molecular frameworks with specific structures by co-crystallization. Additionally, it was shown that trimesic acid is a promising chaperone candidate.

Supplementary Materials: The following are available online at https:/ / www.mdpi.com/article/10 .3390 / cryst11040409/s1, Figure S1: Asymmetric unit of compound (1), with atom labels and 50\% probability displacement ellipsoids. Figure S2: Asymmetric unit of compound (2), with atom labels and $50 \%$ probability dis-placement ellipsoids, the symmetry codes for the generated atoms: $\mathrm{A}(2-\mathrm{x},-\mathrm{y}$, -z). Figure S3: Asymmetric unit of compound (3), with atom labels and 50\% probability displacement ellipsoids. Figure S4: Asymmetric unit of compound (4), with atom labels and 50\% probability displacement ellipsoids. Figure S5: Asymmetric unit of compound (5), with atom labels and 50\% probability dis-placement ellipsoids.

Author Contributions: Conceptualization, G.O. and X.W.; methodology, G.O.; software, G.O.; validation, G.O.; formal analysis, G.O.; investigation, Q.W.; resources, Q.W.; data curation, Q.Z.; writingoriginal draft preparation, G.O.; writing_review and editing, X.W.; visualization, X.W.; supervision, G.O.; project administration, G.O.; funding acquisition, G.O. All authors have read and agreed to the published version of the manuscript.

Funding: This research was funded by the National Natural Science Foundation of China, grant number 51772091, the Scientific Research Fund of Hunan Provincial Education Department, grant number 20A210, and the Construct Program of Applied Characteristic Discipline in Hunan University of Science and Engineering, and the APC was funded by Hunan University of Science and Engineering.

Data Availability Statement: Crystallographic data for (1)-(5) have been deposited with the Cambridge Crystallographic Data Center as supplemental publication numbers CCDC 2069034-2069038, respectively. Copies of the data can be obtained free of charge via http://www.ccdc.cam.ac.uk (accessed on 8 April 2021).

Acknowledgments: We acknowledge Huaqiang Zeng, NanoBio Lab, Singapore 138669.

Conflicts of Interest: The authors declare no conflict of interest.

\section{References}

1. Sharma, C.V.K. Crystal Engineering Where Do We Go from Here. Cryst. Growth Des. 2002, 2, 465-474. [CrossRef]

2. Bernstein, J.; Davey, R.J.; Henck, J.O. Concomitant Polymorphs. Angew. Chem. Int. Ed. 1999, 38, 3340-3461. [CrossRef]

3. James, S.L. Metal-Organic Frameworks. Chem. Soc. Rev. 2003, 32, 276-288. [CrossRef] [PubMed]

4. Yaghi, O.M.; O'Keeffe, M.; Ockwig, N.W.; Chae, H.K.; Eddaoudi, M.; Kim, J. Reticular Synthesis and the Design of New Materials. Nature 2003, 423, 705-714. [CrossRef] [PubMed]

5. Rao, C.N.R.; Natarajan, S.; Vaidhyanathan, R. Metal Carboxylates with Open Architectures. Angew. Chem. Int. Ed. 2004, 43, 1466-1496. [CrossRef]

6. Desiraju, G.R. Cryptic Crystallography. Nat. Mater. 2002, 1, 77-79. [CrossRef]

7. Lin, R.B.; He, Y.; Li, P.; Wang, H.; Zhou, W.; Chen, B. Multifunctional Porous Hydrogen-Bonded Organic Framework Materials. Chem. Soc. Rev. 2019, 48, 1362-1389. [CrossRef]

8. Hisaki, I.; Xin, C.; Takahashi, K.; Nakamura, T. Designing Hydrogen-Bonded Organic Frameworks (HOFs) with Permanent Porosity. Angew. Chem. Int. Ed. 2019, 58, 11160-11170. [CrossRef]

9. Wang, B.; Lin, R.B.; Zhang, Z.; Xiang, S.; Chen, B. Hydrogen-Bonded Organic Frameworks as a Tunable Platform for Functional Materials. J. Am. Chem. Soc. 2020, 142, 14399-14416. [CrossRef]

10. Duchamp, D.J.; Marsh, R.E. The Crystal Structure of Trimesic Acid (Benzene-1, 3, 5-Triearboxylic Acid). Acta Crystallogr. Sect. B 1969, 25, 5-19. [CrossRef]

11. Hosseini, M.W.; Cian, A.D. Crystal Engineering: Molecular Networks Based on Inclusion Phenomena. Chem. Commun. 1998, 727-734. [CrossRef]

12. Zaworotko, M.J. Superstructural Diversity in Two Dimensions: Crystal Engineering of Laminated Solids. Chem. Commun. 2001, 1-9. [CrossRef]

13. Robinson, J.M.A.; Philip, D.; Harris, K.D.M.; Kariuki, B.M. Weak Interactions in Crystal Engineering-Understanding the Recognition Properties of the Nitro Group. New J. Chem. 2000, 24, 799-806. [CrossRef] 
14. Chatterjee, S.; Pedireddi, V.R.; Ranganathan, A.; Rao, C.N.R. Self-Assembled Four-Membered Networks of Trimesic Acid Forming Organic Channel Structures. J. Mol. Struct. 2000, 520, 107-115. [CrossRef]

15. Kolotuchin, S.V.; Fenlon, E.E.; Wilson, R.W.; Loweth, C.J.; Zimmerman, S.C. Self-Assembly of 1,3,5-benzenetricarboxylic acids (Trimesic Acids) and Several Analogues in the Solid State. Angew. Chem. Int. Ed. Engl. 1995, 34, 2654-2657. [CrossRef]

16. Kolotuchin, S.V.; Thiessen, P.A.; Fenlon, E.E.; Wilson, S.R.; Loweth, C.J.; Zimmerman, S.C. Self-Assembly of 1,3,5benzenetricarboxylic (Trimesic) Acid and its Analogues. Chem. Eur. J. 1999, 5, 2537-2547. [CrossRef]

17. Dewa, T.; Endo, K.; Aoyama, Y. Dynamic Aspects of Lattice Inclusion Complexation Involving a Phase Change. Equilibrium, Kinetics, and Energetics of Guest-Binding to a Hydrogen-Bonded Flexible Organic Network. J. Am. Chem. Soc. 1998, 120, 8933-8940. [CrossRef]

18. Krupp, F.; Frey, W.; Richert, C. Absolute Configuration of Small Molecules by Co-Crystallization. Angew. Chem. Int. Ed. 2020, 59, 15875-15879. [CrossRef] [PubMed]

19. Tyler, A.R.; Ragbirsingh, R.; McMonagle, C.J.; Waddell, P.G.; Heaps, S.E.; Steed, J.W.; Thaw, P.; Hall, M.J.; Probert, M.R. Encapsulated Nanodroplet Crystallization of Organic-Soluble Small Molecules. Chem 2020, 6, 1755-1765. [CrossRef]

20. Bhatt, M.B.; Desiraju, G.R. Co-Crystal Formation and the Determination of Absolute Configuration. CrystEngComm 2008, 10, 17471749. [CrossRef]

21. Bryn, M.P.; Curtis, C.J.; Hsiou, Y.; Khan, S.I.; Sawin, P.A.; Kendrick, S.K.; Terzis, A.; Strouse, C.E. Porphyrin Sponges: Conservative of Host Structure in over 200 Porphyrin-Based Lattice Clathrates. J. Am. Chem. Soc. 1993, 115, 9480-9497. [CrossRef]

22. Gruber, T.; Fischer, C.; Seichter, W.; Bombicz, P.; Weber, E. Upper Rim Site Lipophilic Calix[4]arenes as Receptors for Natural Terpenes and Functionally Related Solvent Molecules: Combined Crystal Structure and QMB Sensor Study. CrystEngComm 2011, 13, 1422-1431. [CrossRef]

23. Ceborska, M. Structural Investigation of the $\beta$-cyclodextrin Complexes with Linalool and Isopinocampheol-Influence of Monoterpenes Cyclicity on the Host-Guest Stoichiometry. Chem. Phys. Lett. 2016, 651, 192-197. [CrossRef]

24. Yan, Y.C.; Kariuki, B.M.; Hughes, C.E.; Logsdail, A.J.; Harris, K.D.M. Polymorphism in a Multicomponent Crystal System of Trimesic Acid and t-butylamine. Cryst. Growth Des. 2020, 20, 5736-5744. [CrossRef]

25. Ibenskas, A.; Simenas, M.; Tornau, E.E. Numerical Engineering of Molecular Self-Assemblies in a Binary System of Trimesic and Benzenetribenzoic Acids. J. Phys. Chem. C 2016, 120, 6669-6680. [CrossRef]

26. Goldyn, M.R.; Larowska, D.; Bartoszak-Adamska, E. Novel purine alkaloid cocrystals with trimesic and hemimellitic acids as coformers: Synthetic approach and supramolecular analysis. Cryst. Growth Des. 2021, 21, 396-413. [CrossRef]

27. Rajput, L.; Jana, N.; Biradha, K. Carboxylic acid and phenolic hydroxyl interactions in the crystal structures of cocrystals/clathrates of trimesic acid and pyromellitic acid with phenolic derivatives. Cryst. Growth Des. 2010, 10, 4565-4570. [CrossRef]

28. Bhattacharya, S.; Saha, B.K. Guest-induced isomerization of net and polymorphism in trimesic acid-arylamine complexes. Cryst. Growth Des. 2011, 11, 2194-2204. [CrossRef]

29. Sheldrick, G.M. SADABS, Program for Empirical Absorption Correction of Area Detector Data; University of Göttingen: Göttingen, Germany, 1996.

30. Sheldrick, G.M. Crystal structure refinement with SHELXL. Acta Cryst. A 2015, 71, 3-8. [CrossRef] 